\title{
Festskrift i anledning af professor Asger Berthelsens 70 års fødselsdag den 30. april 1998
}

\author{
LILIAN SKJERNAA
}

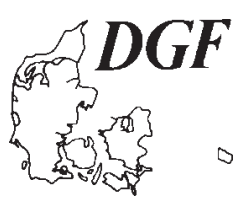

\author{
Skjernaa, L. 2000-02-10. Festskrift i anledning af professor Asger \\ Berthelsens 70 års fødselsdag den 30. april 1998. Bulletin of the Geological \\ Society of Denmark, Vol. 46, pp. 121-123. Copenhagen. \\ https://doi.org/10.37570/bgsd-1999-46-18
}

This volume is in honour of Professor Asger Berthelsen on the occasion of his 70th birthday. Asger Berthelsen has made important contributions within the areas of basement geology, tectonics, structural geology, Quaternary geology, salt tectonics and deep seismic interpretations. He is an outstanding writer and illustrator.

L.Skjernaa [lilians@geo.geol.ku.dk] Geological Institute, University of Copenhagen, Øster Voldgade 10, DK-1350 Copenhagen K, Denmark. 7 January 2000.

\section{Kære Berthel!}

Du startede som dansk geologis vidunderbarn. Du havde publiceret fem videnskabelige artikler, før du tog din magisterkonferens som 25 årig, blev dr. phil. som 32 årig og professor som 33 årig. Nu her ved indgangen til år 2000 står du som dansk geologis »grand old man«. Din betydning for den geologiske videnskab er uomtvistelig, ikke kun set i et dansk eller skandinavisk perspektiv, men også internationalt.

Dette hæfte er, ligesom det symposium vi holdt for dig den 2. oktober 1998, en hyldest til dig fra dine gamle studerende og senere kolleger i anledning af din 70 års dag.

Som ung geologistuderende fik du chancer og ansvar, som nutidens studerende næppe engang drømmer om. Du deltog i ekspeditioner til Grønland og Færøerne, og ikke mindst var du med som eneste geolog på den Centralasiatiske Ekspedition i 1950-51. Dine resultater her vakte opmærksomhed allerede i 1953.

Om den Centralasiatiske ekspedition, og om hvordan du kom til at deltage i den, og det store ansvar du følte, handler din vidunderlige bog fra $1998 »$ Rejsen til den blå s $\varnothing$ «. Den er en fascinerende rejsebeskrivelse og geologisk fører til de fjerne bjergegne i Himalaya, og til en tid og en rejseform som ingen vil kunne opleve i dag. Den bog kan varmt anbefales til alle med interesse for geologi. Den er i det hele taget en guldgrube for alle med rejsefeber og eventyrlyst. Det, som har fascineret mig mest ved bogen, er dog det psykologiske spændingsfelt mellem den unge student som deltager i ekspeditionen og den ældre professor, der fortæller om den. Sammenføringen af dig som 22 årig og som 70 årig.

For os, der har kendt dig og arbejdet sammen med dig i de mellemliggende år, giver bogen en forståelse for baggrunden for din entusiasme og kompromisløshed, når det gælder opklaringen af geologiske problemer. Men også for, at du i rollen som fremragende inspirator og pædagog ind imellem kunne udvise utålmodighed og ironi, som undertiden kunne tangere sarkasme, overfor stu- 


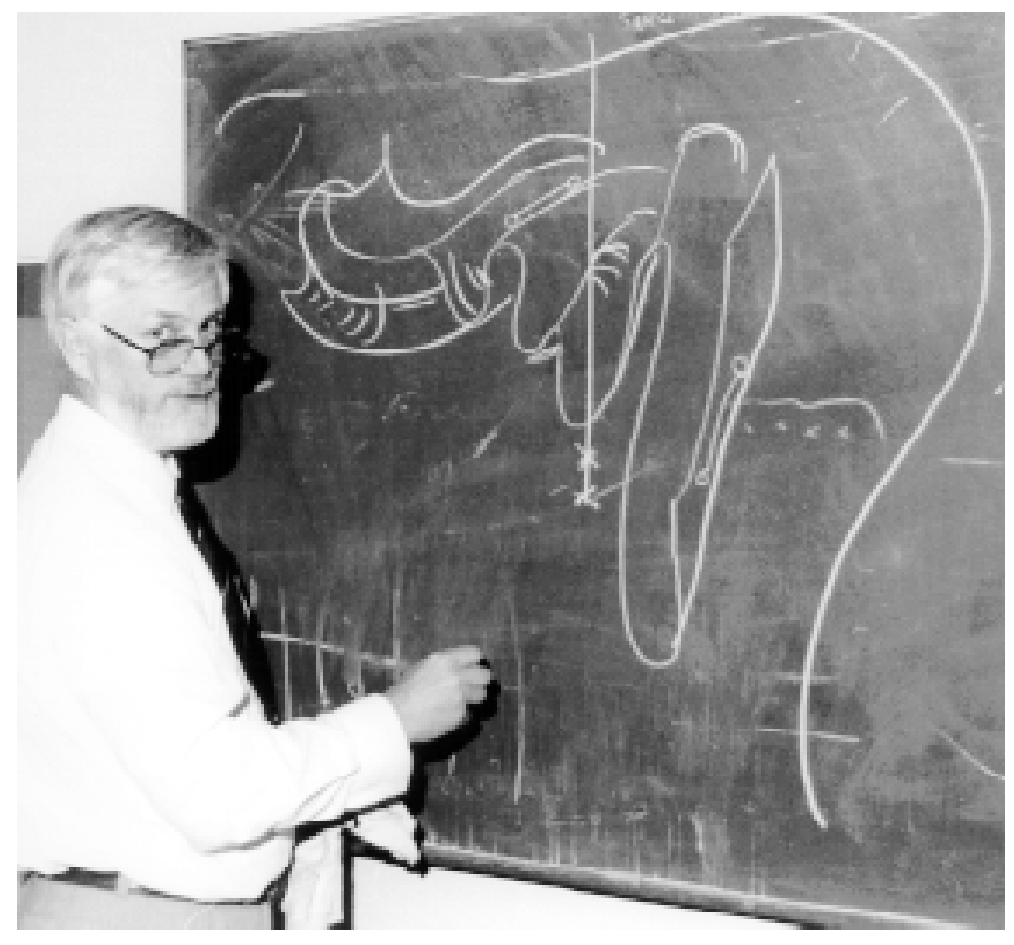

Fig. 1. Asger Berthelsen ved tavlen, 1986.

derende og kolleger, der havde svært ved, eller blot tøvede med, at følge din lynhurtige, kringlede og kreative tankegang.

Som underviser var du i særklasse. Du er i stand til at trylle med en tavle og et stykke kridt (Fig. 1), Alpernes folder, overskydninger og tektoniske vinduer og udviklingen af Skandinaviens grundfjeld blev illustreret, ikke blot som en enkelt tegning, men som en hel tegneserie på tavlen. Dine fremra-

Fig. 2. Asger Berthelsen på sit kontor, 1986.

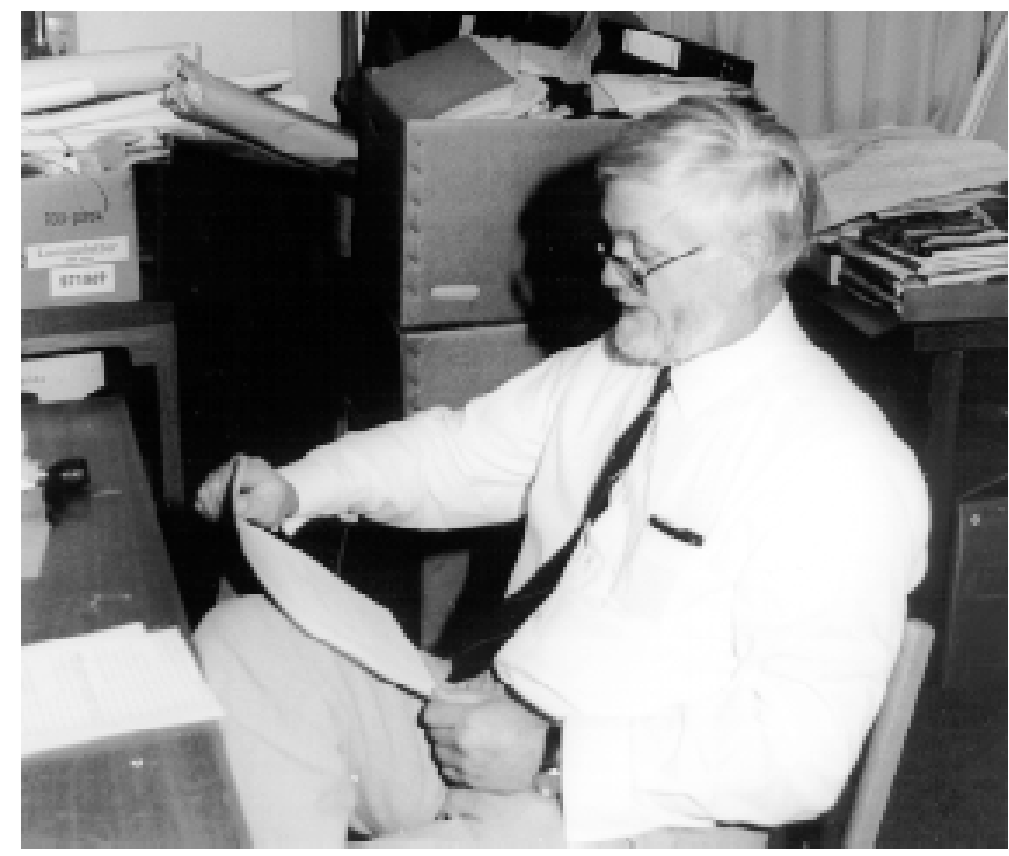

Bulletin of the Geological Society of Denmark 
gende evner som illustrator og formidler af komplekse tre-dimensionelle strukturelle problemstillinger ses i alt hvad du har publiceret. Mange vil huske »Den lille tektoniker « ikke mindst af denne grund. Også tidsskriftet Varv har i mange år trukket på dine evner som formidler, forfatter og illustrator.

»Ordenen « på dit kontor (Fig. 2) har været genstand for mange spøgefulde bemærkninger i tidens løb. På hvert et bord og hver en stol samt på det meste af gulvet var og er der bøger, særtryk, kort og bjergartsprøver i kasser, æsker, bakker og høje stabler; men på forunderlig vis har du næsten altid kunnet finde hvad du søgte. Med Piet Heins ord: »så har hver enkelt henlagt sag et velkendt geologisk lag «.

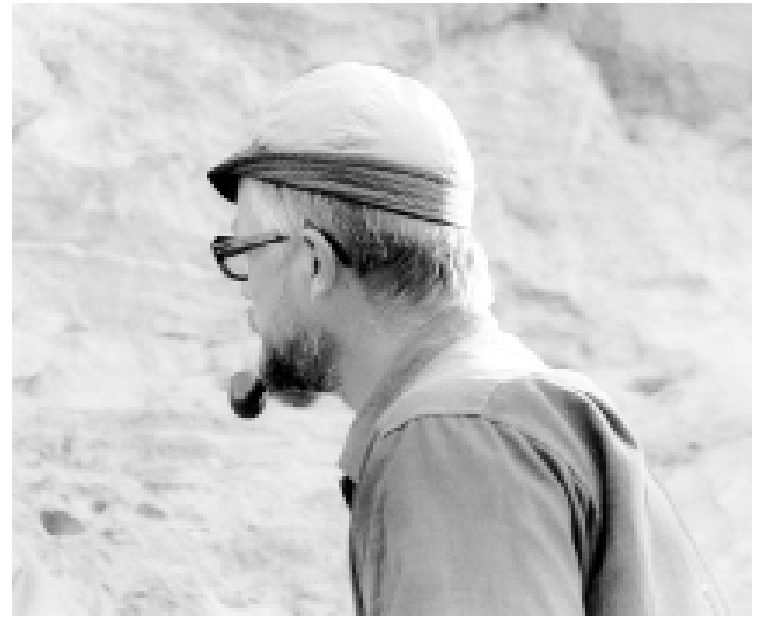

Fig. 3. Asger Berthelsen på feltarbejde på Røsnæs i 1970.

Når man ser tilbage på din videnskabelige kar-

riere, ses det, at du i hvert tiår har kastet dig over en ny geologisk disciplin, fra grundfjeldstektonik til kvartærgeologi, salttektonik og dybseismik. Hver gang har du, med din utrolige geologiske nysgerrighed, din utrættelige indsamling af feltdata (Fig. 3) og din næse for at samle forskelligeartede observationer til en større helhed, bidraget med afgørende nytænkning. Et eksempel herpå er din kineto-stratigrafi, en kvartær-stratigrafisk metode som nu er et standard værktøj, og som iøvrigt blev publiceret i det hæfte af Bulletin of the Geological Society of Denmark, der blev udgivet i 1978 til ære for din gamle læremester, professor Arne Noe-Nygaard i anledning af hans 70 års dag.

Din betydning for og indflydelse på grundfjeldsgeologien har været meget stor. Din udredning af dobbeltfoldestrukturer i de grønlandske gnejser, som bl.a. kom til udtryk i din disputats, var banebrydende. En væsentlig inspiration hertil fik du vistnok, da du opholdt dig hos professor Wegmann i Neuchâtel i 1954, et ophold du ofte har fortalt anekdoter fra. I slutningen af tresserne og gennem halvfjerdserne samlede du en større gruppe studerende og unge kolleger omkring studiet af det sydnorske og sydsvenske grundfjeld, som du selv kørte tyndt i jagten på shearzoner og kræmmerhusfolder. Det var i de år, hvor den nye pladetektoniske model vandt indpas, og du var ikke længe om at tage denne til dig og bruge den i din palinspastiske model for grundfjeldet.

Anledningen til dit engagement i salttektonik var, at der i midten af firserne fra officielt hold var planer om at opbevare højradioaktivt affald fra påtænkte danske atomkraftværker i dybe borede skakter i en salthorst på Mors. Du var den dynamiske anfører for den såkaldte 4-bande fra Geologisk Centralinstitut, som gik til angreb på disse planer, der ud fra en geologisk videnskabelig synsvinkel var hasarderede. Det var en spændende periode, hvor vi blev hvirvlet ind i hele det politiske og mediemæssige spil, som vi ikke tidligere havde haft de store erfaringer med. Vi var oppe mod bl.a. elselskaberne, der var stærke modstandere med store $\emptyset$ konomiske interesser på spil. Vi deltog i møder og konferencer, skrev i aviser og du optrådte i radio og på fjernsyn, var til møde med ledende ministre og fik rig lejlighed til at demonstrere dine evner som popularisator i ordets bedste betydning. Enden på det hele blev, at atomkraftprogrammet blev taget af den politiske dagsorden.

I de sidste mange år har din indsats især taget sigte på at udrede og forklare de helt store strukturer i Jordens lithosfæreplader ud fra dybseismiske signaler.

Kære Berthel, at forsøge at remse dine mange hverv, udgivelser og fortjenester op her ville ikke være hverken muligt eller på sin plads, så på mange kollegers vegne vil jeg slutte med at ønske dig alt godt for de kommende år og endnu engang sige hjertelig til lykke. 